\title{
Burkholderia phytofirmans PsJN Primes Vitis vinifera L. and Confers a Better Tolerance to Low Nonfreezing Temperatures
}

\author{
Andreas Theocharis, Sophie Bordiec, Olivier Fernandez, Sandra Paquis, Sandrine Dhondt-Cordelier, \\ Fabienne Baillieul, Christophe Clément, and Essaïd Ait Barka
}

Université de Reims Champagne-Ardenne, Unité de Recherche Vignes et Vins de Champagne (EA 2069), Laboratoire de Stress, Défense et Reproduction des Plantes, UFR Sciences Exactes et Naturelles, BP 1039, 51687 Reims Cedex 2, France

Submitted 17 May 2011. Accepted 18 September 2011.

\begin{abstract}
Several endophytic bacteria reportedly induce resistance to biotic stress and abiotic stress tolerance in several plant species. Burkholderia phytofirmans PsJN is a plant-growthpromoting rhizobacterium (PGPR) that is able to colonize grapevine tissues and induce resistance to gray mold. Further, PsJN induces physiological changes that increase grapevine tolerance to low nonfreezing temperatures. To better understand how bacteria induced the observed phenomena, stress-related gene expression and metabolite accumulation were monitored in 6-week-old Chardonnay grapevine plantlets after exposure to low nonfreezing temperatures. Under normal conditions $\left(26^{\circ} \mathrm{C}\right)$, plantlet bacterization had no significant effect on the monitored parameters. By contrast, at $4^{\circ} \mathrm{C}$, both stress-related gene transcripts and metabolite levels increased earlier and faster, and reached higher levels in PsJN-bacterized plantlets than in nonbacterized counterparts, in accordance with priming phenomena. The recorded changes may be correlated with the tolerance to cold stress conferred by the presence of PsJN. This is the first time that PGPRinduced priming has been shown to protect plants against low-temperature stress. Moreover, 1 week after cold exposure, levels of stress-related metabolites had declined more in PsJN-bacterized plants, suggesting that the endophyte is involved in the cold acclimation process via the scavenging system.
\end{abstract}

At low, nonfreezing temperatures, cell membranes of coldsensitive plants harden, leading to a disturbance of membranerelated processes such as the opening of ion channels and membrane-associated electron transfer reactions (Uemura and Steponkus 1999). This can have profound effects on plant physiology; for example, reductions in photosynthetic and growth rates (Ait Barka et al. 2006). By contrast, cold-tolerant plant species have evolved mechanisms that enable them to acclimate to low temperatures by minimizing the deleterious effects of cold stress (Gilmour et al. 2000; Xin and Browse 2000) and, thus, maintaining optimal physiological activity at low temperatures.

A number of physiological changes have been related to cold acclimation (Chinnusamy et al. 2006; Nakashima and Yamaguchi-Shinozaki 2006), including general stress-related

A. Theocharis and S. Bordiec contributed equally to this work.

Corresponding author E. Ait Barka: E-mail: ea.barka@univ-reims.fr responses. Hence, cold acclimation has been correlated with accumulation of cryoprotective compounds, such as sugars and proline (Hekneby et al. 2006; Patton et al. 2007); regulation of specific gene expression (Chinnusamy et al. 2006); and synthesis of proteins related to cold stress (Thomashow 1999). Research on cold acclimation has revealed a complex process associated with up- or downregulation of hundreds of genes. For example, transcript levels of cold-regulated, low-temperature-induced, and cold-induced genes greatly increase within a few hours following exposure to cold (Thomashow 1999). The signal transduction pathways leading to expression of coldregulated genes in Arabidopsis thaliana also reportedly involve a regulatory network in which $\mathrm{C}$-repeat binding factor $(\mathrm{CBF})$ transcription factors (CBF1 to $\mathrm{CBF} 3$ ) control many cold-regulated genes during cold acclimation (Tattersall et al. 2007; Xiao et al. 2006, 2008).

In grapevine (Vitis vinifera L.), low temperatures decrease growth and photosynthesis rates (Ait Barka et al. 2006; Bertamini et al. 2005) but increase both carbohydrate metabolism and proline levels (Ait Barka and Audran 1997; Ait Barka et al. 2006). Further, a V. vinifera $C B F 4$ gene, homolog to $A$. thaliana $C B F 1$, recently has been shown to accumulate following exposure to a low temperature $\left(4^{\circ} \mathrm{C}\right)$ and might enhance the survival of overwintering of grape plants (Xiao et al. 2008).

Burkholderia phytofirmans PsJN is a plant-growth-promoting rhizobacterium (PGPR) that can establish rhizospheric and endophytic populations in various plants (Compant et al. 2005a; Nowak and Shulaev 2003). This bacterium stimulates the growth of infected plants and induces physiological changes that enhance their adaptation to environmental stresses (Ait Barka et al. 2000a; Compant et al. 2005a and b; Sharma and Nowak 1998). In grapevine, we recently established that $B$. phytofirmans PsJN colonizes the rhizosphere, penetrates roots, and then migrates through all plant tissues within $94 \mathrm{~h}$ of bacterial application (Compant et al. 2005b). Furthermore, the presence of the bacterium in the plant promotes post-chilling recovery by improving acclimation to chilling temperatures, manifested in lower cell damage, higher photosynthetic activity, and accumulation of cold-stress-related metabolites such as starch, proline, and phenolic compounds (Ait Barka et al. 2006). Plants can establish a distinct physiological state, the socalled "primed" state (Conrath 2009; Frost et al. 2008; Ton et al. 2005), following root colonization by beneficial microbes, infection by necrotizing pathogens, or after treatment with various chemicals; for instance, exogenous application of low doses of salicylic acid (SA), jasmonic acid (JA), or $\beta$-aminobutyric 
acid. Primed plants respond by activating defense responses faster or more strongly when subsequently challenged by microbial pathogens or herbivorous insects (Conrath 2009; Pozo et al. 2008). However, the defense responses of primed plants are not induced directly by the priming agent but are activated more rapidly following perception of biotic or abiotic stress signals, resulting in an enhanced level of resistance against the encountered stressor. This defense priming adds another layer of complexity to the adaptive responses of plants to their environment.

Considerable progress has been made toward understanding the molecular and physiological mechanisms underlying bacterial-mediated tolerance to biotic stresses. However, although bacterially mediated resistance to various abiotic stresses has also been reported, the mechanisms involved remain largely elusive (Dimkpa et al. 2009). The beneficial interaction between the grapevine and $B$. phytofirmans PsJN, particularly how the presence of the bacterium helps the plant to withstand cold stress, requires elucidation. Therefore, we have analyzed the ability of the bacterium to potentiate (i) the expression of defense- and cold-related genes and (ii) associated changes in levels of sev- eral stress-related metabolites, including proline, malondialdehyde (MDA), and aldehydes (ALD) known as lipid peroxidation (LP) markers, and hydrogen peroxide $\left(\mathrm{H}_{2} \mathrm{O}_{2}\right)$.

\section{RESULTS}

\section{Gene expression.}

For all considered genes, our results indicate that basal levels of gene expression were similar in PsJN-bacterized and nonbacterized plantlets grown at $26^{\circ} \mathrm{C}$ (Fig. 1). Following exposure to low temperatures $\left(4^{\circ} \mathrm{C}\right)$, transcript levels of all the genes (except lipoxygenase [LOX]) rose significantly in both bacterized and nonbacterized plants but more strongly in the former (Fig. 1).

After $24 \mathrm{~h}$ of cold exposure, expression of stilbene synthase (STS) and phenylalanine ammonia-lyase (PAL) genes was enhanced in PsJN-bacterized plantlets by 460 - and 40 -fold, respectively, but only by 150 - and 9 -fold in the nonbacterized plantlets (Fig. 1A and B). After $48 \mathrm{~h}$ of cold exposure, transcript levels decreased but remained higher in bacterized plantlets. After 2 weeks of treatment, no differences in these transcript

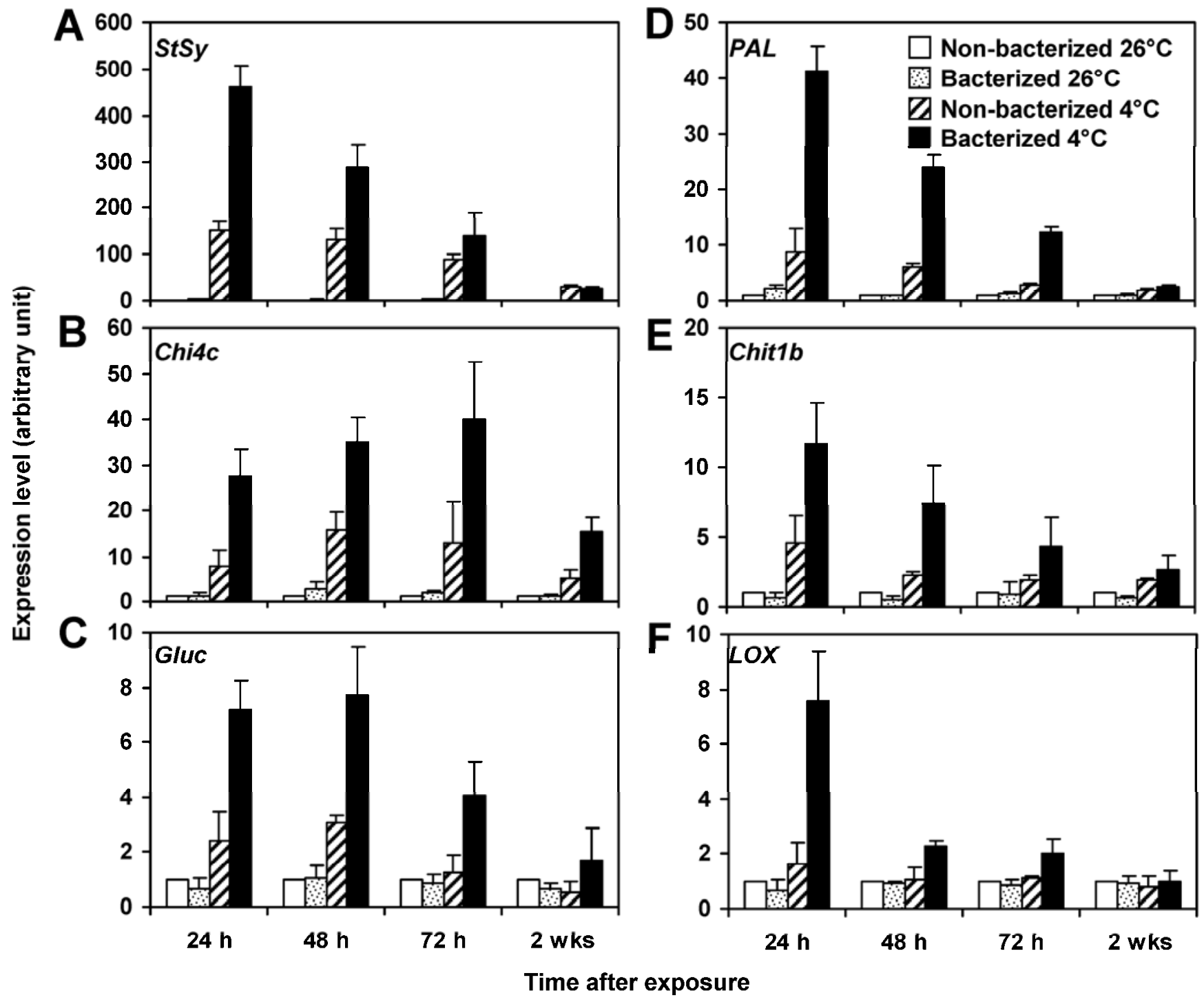

Fig. 1. Expression levels of the defense genes A, StSy; B, PAL; C, Chit $4 c ; \mathbf{D}$, Chit $1 b ; \mathbf{E}$, Gluc; and $\mathbf{F}, L O X$ in leaves of nonbacterized and bacterized grapevine plantlets after 24,48 , and $72 \mathrm{~h}$ and 2 weeks of cold treatment. Results represent mean fold increases (x-fold) in mRNA levels, \pm standard deviation, relative to those of control plantlets (nonbacterized, maintained at $26^{\circ} \mathrm{C}$ ) obtained from three independent experiments. White bars, nonbacterized $26^{\circ} \mathrm{C}$; dotted bars, bacterized $26^{\circ} \mathrm{C}$; dashed bars, nonbacterized $4^{\circ} \mathrm{C}$; black bars, bacterized $4^{\circ} \mathrm{C}$. 
levels were recorded between bacterized and nonbacterized plantlets.

Considering genes encoding pathogenesis-related (PR) proteins, Chit $4 c$ transcripts accumulated gradually in bacterized plantlets, peaking (40-fold) after $72 \mathrm{~h}$ of cold treatment (Fig. 1C). After 2 weeks of treatment, transcript levels remained 15fold above the basal level. In nonbacterized plantlets, the pattern was similar but the peak level was lower. Chit1b expression was increased 12 -fold after $24 \mathrm{~h}$ of cold exposure in bacterized plantlets and then decreased gradually until the end of the experiment (Fig. 1D). In nonbacterized plantlets, expression was only enhanced by a factor of four after $24 \mathrm{~h}$. Similarly, Gluc expression was stimulated following cold treatment (peak at $48 \mathrm{~h}$ ) and to a greater extent in bacterized plantlets (Fig. 1E).

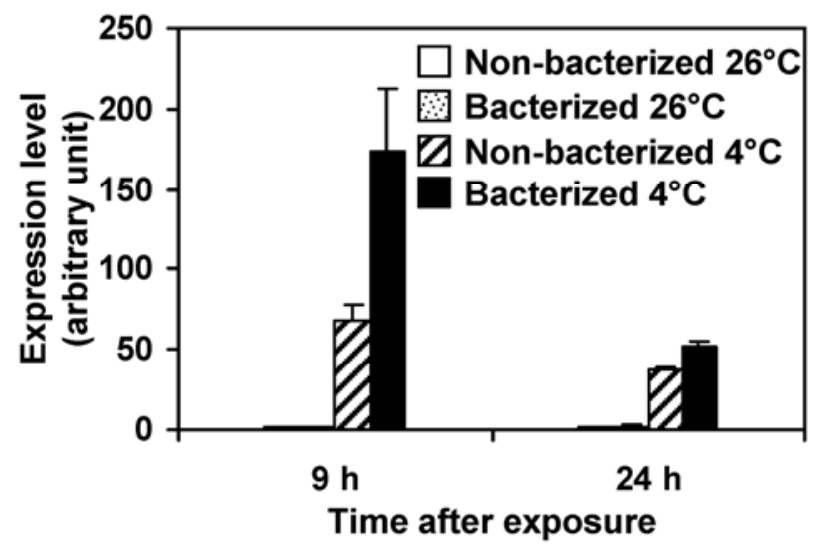

Fig. 2. C-repeat binding factor $(C B F) 4$ expression levels in leaves of nonbacterized and bacterized grapevine plantlets after 9 and $24 \mathrm{~h}$ of cold treatment. Results represent mean fold increases in mRNA levels, \pm standard deviation, relative to those of control plantlets (nonbacterized, maintained at $26^{\circ} \mathrm{C}$ ) obtained from a duplicate of one representative experiment out of three independent experiments. White bars, nonbacterized $26^{\circ} \mathrm{C}$; dotted bars, bacterized $26^{\circ} \mathrm{C}$; dashed bars, nonbacterized $4^{\circ} \mathrm{C}$; black bars, bacterized $4^{\circ} \mathrm{C}$.
By contrast with the other tested genes, cold exposure induced $L O X$ expression (Fig. 1F) only in bacterized plantlets, with a transient peak of expression after $24 \mathrm{~h}$ of cold treatment (7.5-fold). These findings are consistent with results of a previous microarray analysis (Wong et al. 2006) showing that cold treatment induced transcripts encoding a putative $L O X$ (At1g17420) gene in Thellungiella spp. (Bell and Mullet 1993).

To analyze expression of transcription factor $C B F 4$, leaves were sampled earlier than for other genes, because induction of the Vitis $C B F 4$ gene reduction reportedly peaks $9 \mathrm{~h}$ after the application of cold stress (Xiao et al. 2008). As we had hypothesized, the results showed that transcripts of $C B F 4$ were upregulated in plantlets $9 \mathrm{~h}$ after cold exposure (Fig. 2). Gene expression peaked at 60- and 160-fold, relative to basal levels, in nonbacterized and PsJN-bacterized plants, respectively. $C B F 1$ to $C B F 3$ gene expression was not induced in this study (data not shown).

\section{Stress-related metabolites.}

Proline content. Under normal temperature conditions $\left(26^{\circ} \mathrm{C}\right)$, the levels of free proline in the PsJN-bacterized and nonbacterized plantlets were similar during the first 3 days and became significantly higher $(P<0.05)$ in bacterized plantlets after 1 week (Fig. 3). By contrast, after exposure to $4^{\circ} \mathrm{C}$, the proline content increased gradually during the chilling treatment in both bacterized and nonbacterized plantlets, compared with plantlets maintained at $26^{\circ} \mathrm{C}$. However, the proline content in the PsJN-inoculated plantlets was higher than that of the noninoculated plantlets at the end of the cold exposure.

ALD and MDA contents. ALD and MDA, which are secondary end products of polyunsaturated fatty acid oxidation, indicate the degree of LP. Under normal conditions, there was no significant difference in contents of ALD and MDA between PsJN-bacterized and nonbacterized plantlets (Fig. 4). However, after exposure to $4^{\circ} \mathrm{C}$, both ALD and MDA levels showed sharp increases after the first few days that were stronger in the PsJN-bacterized plantlets. After $72 \mathrm{~h}$ of treatment, ALD and MDA contents were similar in both bacterized and nonbacter-

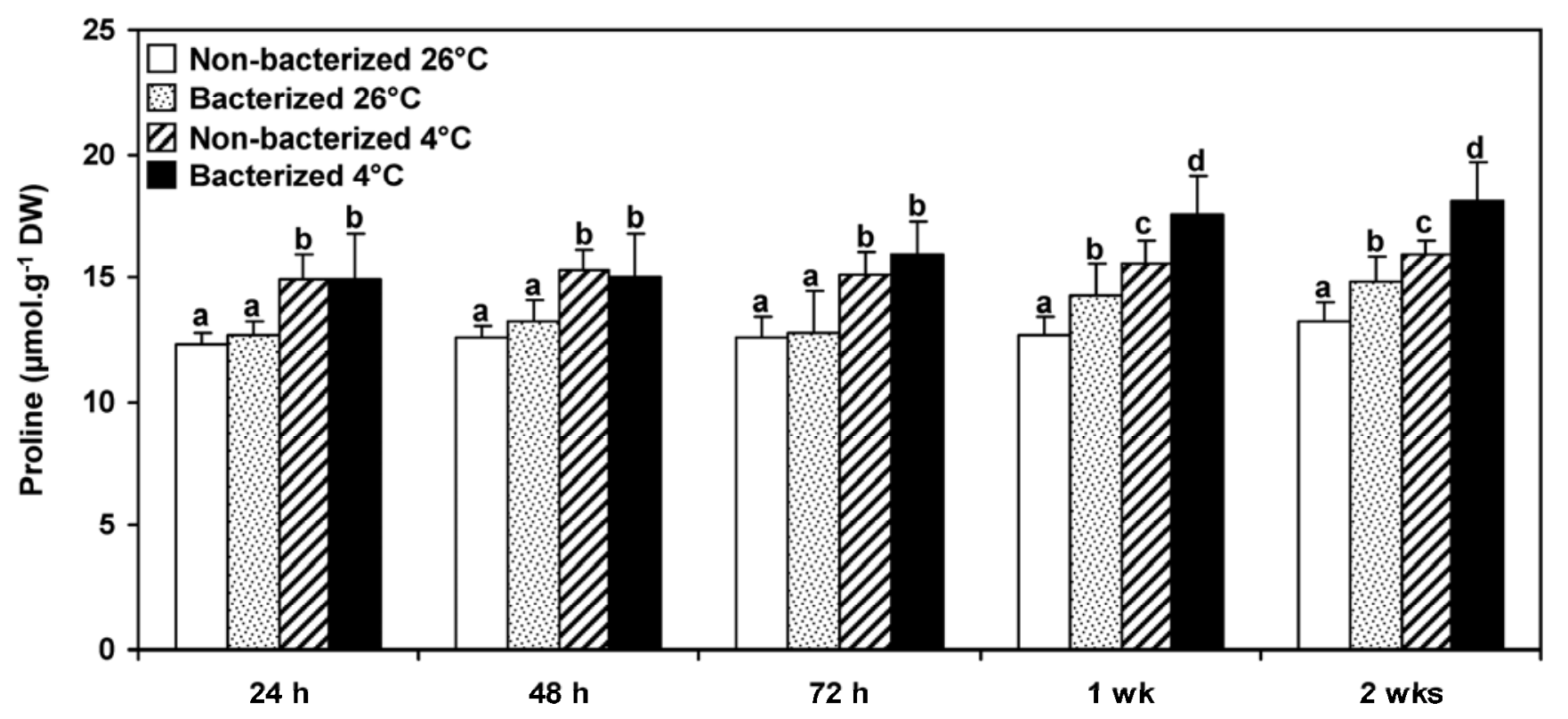

Time after exposure

Fig. 3. Accumulation of proline in nonbacterized and bacterized grapevine plantlets after 24, 48, and $72 \mathrm{~h}$ and 1 and 2 weeks of cold treatment. Means indicated with different letters are significantly different $(P<0.05)$. Data are means of three independent experiments \pm standard deviation. White bars, nonbacterized $26^{\circ} \mathrm{C}$; dotted bars, bacterized $26^{\circ} \mathrm{C}$; dashed bars, nonbacterized $4{ }^{\circ} \mathrm{C}$; black bars, bacterized $4{ }^{\circ} \mathrm{C}$. 
ized plantlets; then, after the first week, the ALD and MDA contents decreased, particularly in PsJN-bacterized plantlets.

$\mathrm{H}_{2} \mathrm{O}_{2}$ accumulation. Under normal conditions, the $\mathrm{H}_{2} \mathrm{O}_{2}$ production rate did not significantly differ between PsJN-bacterized and nonbacterized plantlets (Fig. 5). By contrast, exposure to low temperatures caused increases in $\mathrm{H}_{2} \mathrm{O}_{2}$ production in both bacterized and nonbacterized grapevine plantlets within the first $72 \mathrm{~h}$ of treatment but to a higher extent in the former. As for ALD and MDA, after 1 week of treatment, $\mathrm{H}_{2} \mathrm{O}_{2}$ production in noninoculated plantlets remained significantly higher than in the PsJN-bacterized plantlets, in which it decreased significantly.

\section{DISCUSSION}

The endophytic B. phytofirmans PsJN has been characterized as a PGPR that induces systemic resistance against fungal pathogens (Compant et al. 2008a and b; Sharma and Nowak
1998). Furthermore, we have previously shown that PsJN can colonize entire grapevine tissues, from the roots to inflorescences, without damaging the plant (Compant et al. 2005b, 2008a). Results of the present study show that, under normal conditions $\left(26^{\circ} \mathrm{C}\right)$, the presence of the bacterium caused no significant induction of stress-related gene expression or metabolite accumulation, supporting the hypothesis that it forms a mutualistic relationship with the grapevine. The same conclusion was drawn by Bordiec and associates (2011), who reported that, whereas the PsJN bacterium is perceived by grapevine cells, the defense responses are significantly weaker than those in a nonhost interaction.

Furthermore, the bacterium also enhances grapevine tolerance to cold stress (Ait Barka et al. 2006). Similar conclusions have been reported for the interaction between Chorispora bungeana and the endophyte Clavibacter sp. strain Enf12 (Ding et al. 2011). However, little information is available on the molecular changes induced that trigger regulatory and bio-

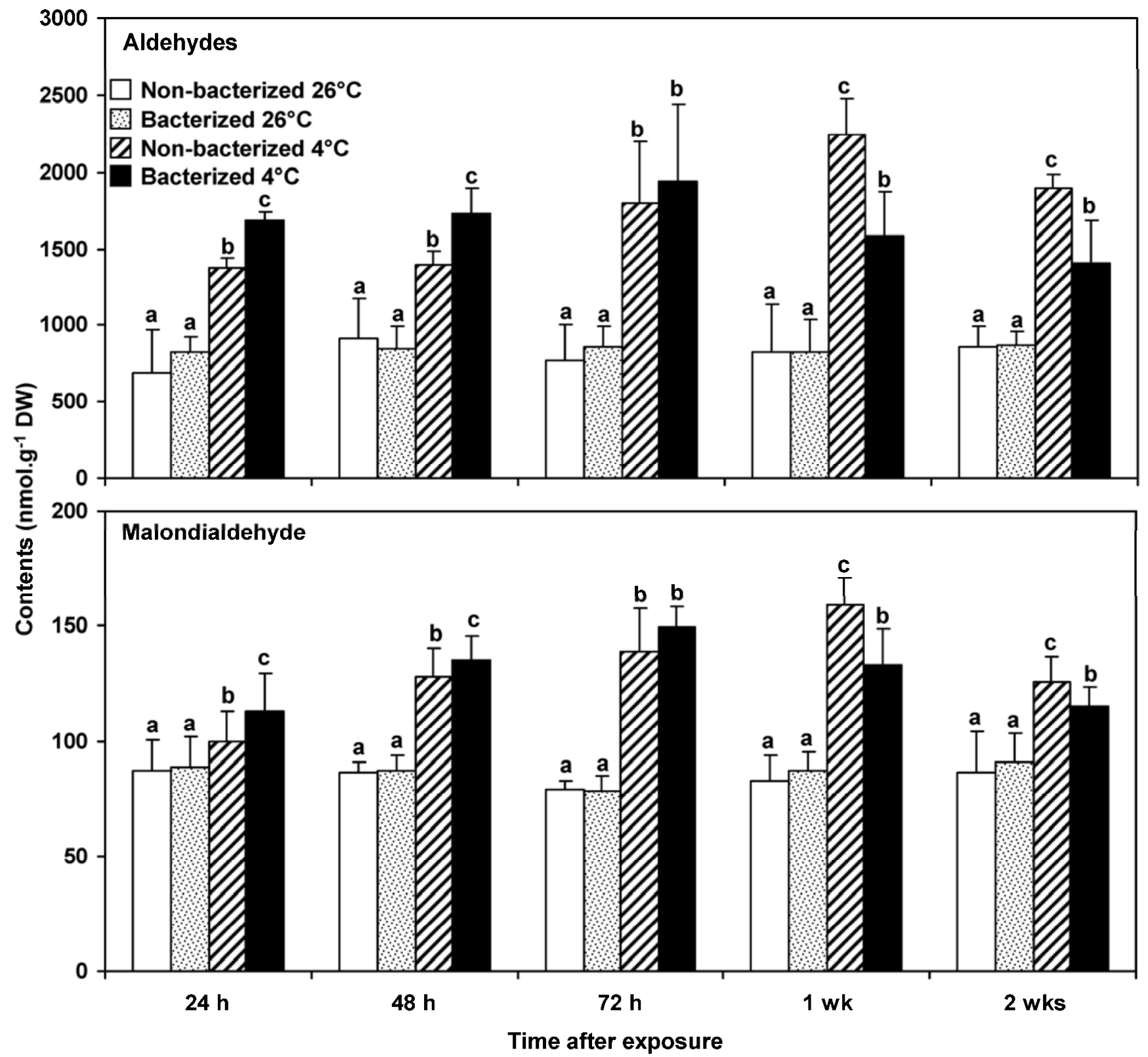

Fig. 4. Levels of aldehydes and malondialdehyde in nonbacterized and bacterized grapevine plantlets after 24, 48, and $72 \mathrm{~h}$ and 1 and 2 weeks of cold treatment. Data indicate means obtained from three independent experiments \pm standard deviation, and means marked with different letters are significantly different $(P<0.05)$. White bars, nonbacterized $26^{\circ} \mathrm{C}$; dotted bars, bacterized $26^{\circ} \mathrm{C}$; dashed bars, nonbacterized $4{ }^{\circ} \mathrm{C}$; black bars, bacterized $4{ }^{\circ} \mathrm{C}$. 
chemical mechanisms conferring the improvement in tolerance of low temperatures. Key responses to low temperatures in plants include cascades of events leading to changes in gene expression and, subsequently, biochemical and physiological modifications that enhance their resistance (Zhou et al. 2008). Thus, to gain a better understanding of the PsJN-mediated improvement of chilling tolerance, we examined associated changes in levels of stress-related biochemical markers and gene transcripts. We found their levels to be substantially higher in PsJN-bacterized grapevine exposed to low temperatures than in both nonbacterized plants and counterparts maintained at $26^{\circ} \mathrm{C}$, clear indications that the presence of the bacterium "primes" the plant.

STS and PAL were selected for study because of their roles in synthesis of resveratrol and SA, respectively, two major compounds implicated in plant stress responses (Chong et al. 2009; Gaudet et al. 2003). The expression of StSy genes is often induced in grapevine subjected to various stresses, including pathogen infection (Preisig-Muller et al. 1999), ozone treatment (Brehm et al. 1999), and UV light (Versari et al. 2001). Storage at $0^{\circ} \mathrm{C}$ for 3 days also increases VcSTS (and $V c P A L)$ mRNA levels in the skin of red table grape ( $V$. vinifera L. 'Cardinal') according to Sanchez-Ballesta and associates (2007). The induction of $P A L$ following cold exposure has been observed in transcriptomic analysis of winter wheat (Gaudet et al. 2003), and $P A L$ is regarded as a reliable marker of the primed state, because increases in either $P A L$ expression or activities of the encoded enzyme have been observed following challenges of: tobacco with Tobacco mosaic virus after pretreatment with chemicals (Conrath et al. 2006), parsley cell suspensions with benzothiadiazole (Thulke and Conrath 1998), and asparagus with Fusarium oxysporum f. sp. asparagi after SA treatment (He and Wolyn 2005). In accordance with these previous findings, in the present study, StSy and PAL expression was induced in response to low temperatures and was clearly primed in PsJN-chilled plantlets.

The effects of the bacterium and chilling treatments on expression of the $L O X$ ( $L O X$-encoding) gene were also investigated, because it is involved in the synthesis of oxylipins and reactive oxygen species (ROS) regulation, both of which play important roles in responses to biotic (Aziz et al. 2003; Bordiec et al. 2011) and cold stress (Ruelland et al. 2009).

$L O X$ responses differed from those of the other tested genes, because its expression was induced by exposure to low temperature only in PsJN-bacterized plantlets. Similarly, Hamiduzzaman and associates (2005) found that LOX expression is only strongly induced in grapevine after infection with Plasmopara viticola if the infection is preceded by a $\beta$-aminobutyric acid (BABA) priming treatment, and evidence that $L O X$ is regulated by JA. Thus, the marked expression of $L O X$ in bacterized plantlets after cold treatment suggests that the JA signal transduction pathway could be involved in the cold acclimation process induced by $B$. phytofirmans. The results obtained in our study may appear incongruous in terms of oxidative metabolism, because $L O X$ is known to cause peroxidative damage in plasma membrane through LP (Lee et al. 2005), which is deleterious to plant cells, in contrast to the suspected beneficial effect of priming on plant stress defenses. However, a week after starting cold exposure, levels of LP markers and $\mathrm{H}_{2} \mathrm{O}_{2}$ declined more rapidly in bacterized than in nonbacterized plantlets, suggesting the occurrence of unknown mechanisms that promoted ROS and LP elimination, and may be involved in plant acclimation to cold stress under bacterized conditions.

We also monitored three genes encoding PR proteins, two acidic chitinases (chit4c and chitlb) and a basic glucanase $(g l u c)$, known for their involvement in grapevine resistance to pathogen attacks (Bordiec et al. 2011; Varnier et al. 2009) and antifreeze activities (Griffith and Yaish 2004). Hence, they may be classified as either antifreeze proteins (Griffith and Yaish 2004) or PR proteins (Van Loon and Van Strien 1999) and, unsurprisingly, their expression increased following exposure to low temperatures because they exhibit both antifreeze and antifungal activities; thus, they have been extensively analyzed in plants exposed to cold or pathogen attack (Huang and Duman 2002; Van Loon and Van Strien 1999; Yeh et al. 2000).

The best-understood genetic pathway that leads to gene induction upon exposure to low temperature is based on $\mathrm{CBF}$

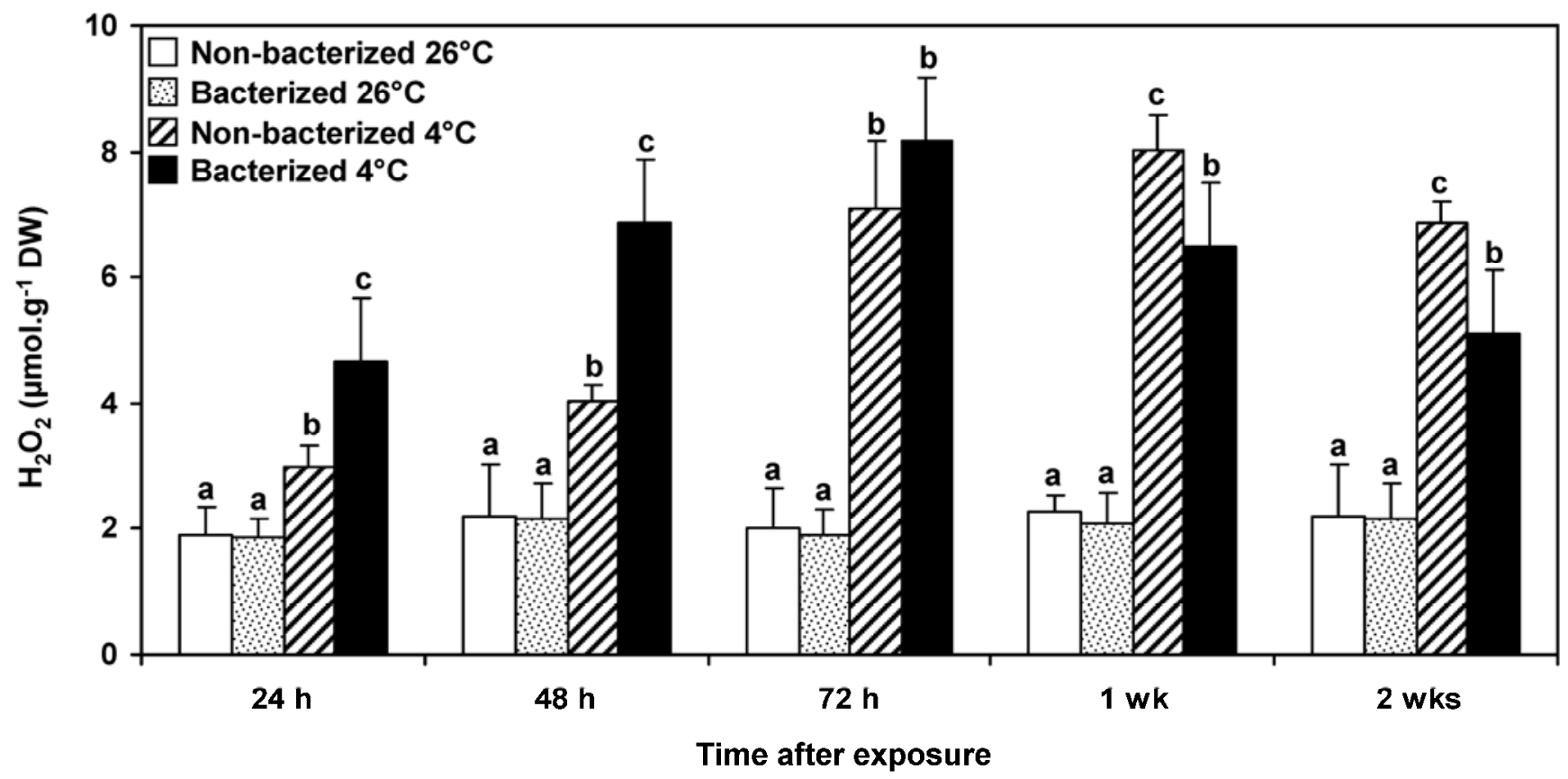

Fig. 5. Levels of hydrogen peroxide $\left(\mathrm{H}_{2} \mathrm{O}_{2}\right)$ in nonbacterized and bacterized grapevine plantlets after 24,48 , and $72 \mathrm{~h}$ and 1 and 2 weeks of cold treatment. Data indicate means obtained from three independent experiments \pm standard deviation, and means marked with different letters are significantly different $(P<0.05)$. White bars, nonbacterized $26^{\circ} \mathrm{C}$; dotted bars, bacterized $26^{\circ} \mathrm{C}$; dashed bars, nonbacterized $4^{\circ} \mathrm{C}$; black bars, bacterized $4^{\circ} \mathrm{C}$. 
transcription factors, which activate promoters through the C-repeat cis element (Ruelland et al. 2009). In our grapevine plantlets, low temperatures induced the transcription of the cold-specific transcription factor $C B F 4$ after $9 \mathrm{~h}$ and, later, after $24 \mathrm{~h}$, the accumulation of other defense-related gene transcripts, as well as the stress-related metabolites. These responses were stronger and faster in PsJN-bacterized plantlets. This may be correlated with our previous findings that bacterized-leaf cells are less affected by deleterious effects of cold than nonbacterized cells (Ait Barka et al. 2006). In A. thaliana, the expression of $C B F$ transcription factors is reportedly stimulated rapidly (within $2 \mathrm{~h}$ ) during cold treatment (Gilmour et al. 2000; Liu et al. 1998). Following their discovery in Arabidopsis, many CBF homologues have been found in both monocotyledons and dicotyledons that can acclimate to cold, but they are also found in species that apparently (Ruelland et al. 2009). Grapevine has five $C B F$ genes: $C B F 1$ to $C B F 4$ (Xiao et al. 2006, 2008) and an undefined CBF-like transcription factor, CBFL (XM_002270601). CBF genes, particularly CBF4, are reportedly induced within a few hours after exposure to low temperatures (Xiao et al. 2008) and, very recently, Takuhara and associates (2011) demonstrated that low temperature enhances expression of $V v C B F 2, V v C B F 4$, and $V v C B F L$ (but not $V v C B F 1$ or $V v C B F 3$ ) within $3 \mathrm{~h}$. By contrast, in the present study, we did not detect induction of $C B F 1$ to $C B F 3$ transcription in response to low temperature but we found clear induction of $C B F 4$ after $9 \mathrm{~h}$ of cold treatment. The differences in observed responses could be due to differences in either experimental design or ages of the leaves used. In support of the latter hypothesis, Xiao and associates (2006) found that leaf age affected the enhancement of $C B F 1, C B F 2$, and $C B F 3$ (but not $C B F 4$ ) transcription in response to low temperature. Thus, although both we and Xiao and associates (2006) used young leaves in our experiments, differences in leaf conditions may have affected $C B F 1$ to $C B F 3$ expression.

In addition to gene expression, plant responses to cold also lead to changes in levels of stress-related metabolites, such as proline, $\mathrm{H}_{2} \mathrm{O}_{2}$, and ALD. Proline is the best-characterized stress-responsive molecule, is often synthesized by plants in response to diverse abiotic or biotic stresses (acting as a membrane stabilizer, osmo-protector, enzyme regulator, or ROS scavenger), and is often associated with plant resistance to low temperature (Chen and Li 2002; Wang et al. 2008). It probably participates in the regulation of cytosol $\mathrm{pH}$, stabilization of NAD+/NADH ratios, maintenance of the photochemical activity of photosystem II in thylakoid membranes, and limitation of LP (Kishor et al. 2005). Unsurprisingly, therefore, we previously found that proline accumulates in grapevine both in response to cold shocks (Ait Barka and Audran 1997) and during cold acclimation (Ait Barka et al. 2006). In the present study, the proline content was higher in the PsJN-inoculated plantlets than in the nonbacterized plantlets at the end of the cold exposure, in accordance with conclusions by Ding and associates (2011) that increases in proline enhance the chilling tolerance of $C$. bungeana plantlets.

Low-temperature stress leads to an increase of oxidative stress due to increases in levels of ROS, leading to LP and, hence, ion leakage (Pinhero et al. 1997). Among ROS, $\mathrm{H}_{2} \mathrm{O}_{2}$ has varying effects on plants subjected to low temperatures depending on the nature of the exposure (Prasad et al. 1994). Under cold shock, $\mathrm{H}_{2} \mathrm{O}_{2}$ accumulates to damaging levels in plant tissues, because levels of antioxidant enzymes are low. By contrast, in cold-acclimated plants, $\mathrm{H}_{2} \mathrm{O}_{2}$ may trigger the synthesis of antioxidant enzymes, such as catalase or peroxidase, which scavenge ROS and help the plant to withstand cold conditions. Our results show that the presence of B. phytofirmans in plantlets induced stronger $\mathrm{H}_{2} \mathrm{O}_{2}$ accumulation within the first 3 days of cold treatment and accelerated the elimination of $\mathrm{H}_{2} \mathrm{O}_{2}$ after a week, probably due to the induction of antioxidative mechanisms, which enhance neutralization of the toxic effect of ROS (Ding et al. 2011).

Chilling stress usually induces peroxidation of membrane lipids by ROS accumulation, manifested in the formation of MDA, a secondary end product of polyunsaturated fatty acid oxidation, followed by disruption of metabolic functions and loss of cellular integrity (Imahori et al. 2008). The level of MDA can reflect the oxidative damage status, as well as the integrity of membranes, of plants subjected to low temperatures. During the first period of chilling, levels of both ALD and MDA were significantly higher in PsJN-bacterized grapevine. However, the pattern subsequently reversed, probably due to effects of a scavenging system, which provided additional neutralization of the toxic effect of ROS. Thus, B. phytofirmans accelerated grapevine reactions and, subsequently, induced acclimation to cold exposure. The same conclusions were reached by Ding and associates (2011), who reported that Enf12 protects $C$. bungeana against chilling, at least partly through the upregulation of antioxidant enzymes. Thus, our results are in accordance with previous reports, which have shown that plant colonization by endophytic bacteria may modulate the activity of plant antioxidant enzyme activities at an early stage in the development of plant tolerance to various stresses (Ding et al. 2011; Pavlo et al. 2011).

In several cold-sensitive plant systems, chilling temperatures also induce increases in ethylene production via increases in levels of ethylene precursors or the activities of enzymes involved in its biosynthetic pathway (Concellon et al. 2005). Further, fruit of an anti-sense ACC-oxidase genotype of cantaloupe melon display less membrane deterioration and damage (correlated with very low ethylene production) than wild-type fruit during low-temperature storage (Ben-Amor et al. 1999).

PsJN expresses high levels of 1-aminocyclopropane-1-carboxylate deaminase (Sessitsch et al. 2005), which hydrolyzes the ethylene precursor 1-aminocyclopropane-1-carboxylate to ammonia and $\alpha$-ketobutyrate, thereby reducing the damaging effects of cold by lowering the production of ethylene in planta.

In addition to any direct effects (and perhaps more importantly), several studies of systemic resistance to pathogens have found that PGPR primes plant defense reactions (Tjamos et al. 2005; Van Wees et al. 2008). In grapevine, the priming of defense mechanisms that enhance pathogen resistance has been demonstrated in plants treated with BABA or sulfated laminarin PS3 prior to challenges with downy mildew (Hamiduzzaman et al. 2005; Slaughter et al. 2008; Trouvelot et al. 2007). Recently, grapevine physiological responses against Botrytis cinerea have also been shown to be potentiated by nonpathogenic rhizobacteria Pseudomonas spp. (Verhagen et al. 2010). In our experiment, PGPR Burkholderia phytofirmans PsJN primed grapevine plantlets responses to low, nonfreezing temperatures: at $26^{\circ} \mathrm{C}$, levels of both stress-related transcripts and metabolites were identical in PsJN-bacterized and nonbacterized plantlets but, after exposure to cold, they were higher in the bacterized plantlets. To the best of our knowledge, this demonstrates for the first time that PGPR B. phytofirmans PsJN acts as a priming agent for defense responses in grapevine plantlets against low temperatures $\left(4^{\circ} \mathrm{C}\right)$.

In many examined interactions between plants and beneficial microorganisms, induced resistance is not correlated with direct activation of defense-related genes but is associated with defense responses that are activated upon pathogen or insect attack. To date, the costs and benefits associated with priming have been poorly investigated. Recently, it was reported that the fitness costs of priming are lower than those of constitu- 
tively activated defenses, and that the costs of priming are outweighed by its benefits under disease pressure, suggesting that priming is an effective strategy for plants to cope with environmental stress (Conrath 2009). In conclusion, plant colonization by the endophytic PsJN places grapevine metabolism in a state of alert (primed), rather than wastefully activating defenses, thereby enabling rapid and intense resistance responses to subsequent stress. Apart from facilitating cold tolerance, this status may also participate in the resistance of bacterized grapevine plantlets against Botrytis cinerea. The present work provides novel insights into the molecular mechanisms of defense-priming and may facilitate the development of novel strategies for durable crop protection.

\section{MATERIALS AND METHODS}

\section{Plant material and in vitro growth conditions.}

Plantlets of $V$. vinifera 'Chardonnay' clone 7535 were micropropagated by nodal explants grown on $15 \mathrm{ml}$ of agar medium in 25-mm culture tubes, as described earlier (Ait Barka et al. 2006). They were then cultivated in a growth chamber under white fluorescent light $\left(200 \mu \mathrm{mol} \mathrm{m} \mathrm{m}^{-2} \mathrm{~s}^{-1}\right)$ with $16 \mathrm{~h}$ of light per day at a constant $26^{\circ} \mathrm{C}$.

\section{Bacterial inoculums.}

The bacterial inoculum was produced by transferring two loops of Burkholderia phytofirmans PsJN tagged with green fluorescent protein (GFP) (Sessitsch et al. 2005) to $100 \mathrm{ml}$ of King's B liquid medium in a 250-ml Erlenmeyer flask, then incubating at $20^{\circ} \mathrm{C}$ at $150 \mathrm{rpm}$ for $48 \mathrm{~h}$. Bacteria were collected by centrifugation $(3,000 \times g$ for $15 \mathrm{~min})$ and washed twice with phosphate-buffered saline (PBS) (10 mM, pH 6.5). The pellet was resuspended in PBS and used as inoculum. The bacterium concentration was estimated by spectrophotometry $(600 \mathrm{~nm})$ and adjusted to $3 \times 10^{8} \mathrm{CFU} \mathrm{ml}^{-1}$ with PBS (Ait Barka et al. 2006).

\section{Plant bacterization.}

Roots of 2-week-old plantlets were immersed in bacterial inoculum $\left(3 \times 10^{8} \mathrm{CFU} \mathrm{ml}{ }^{-1}\right)$ or PBS (control) for $10 \mathrm{~s}$. Plantlets were then grown as described above for 4 weeks before cold treatment. Endophytic colonization was confirmed by visualizing the presence of GFP-tagged strain PsJN around leaves detached from bacterized plantlets after 4 days at $28^{\circ} \mathrm{C}$ on solid Luria-Bertani medium.

\section{Cold treatment.}

Four weeks later, half of the PsJN-bacterized and nonbacterized plantlets were transferred to a cold growth chamber in which temperature was maintained at $10^{\circ} \mathrm{C}$ under $16 \mathrm{~h}$ of light (white fluorescent light, $200 \mu \mathrm{mol} \mathrm{m}{ }^{-2} \mathrm{~s}^{-1}$ ) and at $4^{\circ} \mathrm{C}$ for $8 \mathrm{~h}$ of darkness. The other set of plantlets (controls) was kept under the standard conditions as described above $\left(26^{\circ} \mathrm{C}\right)$.
Analysis of gene expression.

Sampling, DNase treatment, RNA extraction, and synthesis of $c D N A$. Leaf samples were frozen in liquid nitrogen and stored at $-80^{\circ} \mathrm{C}$ until use, then ground in liquid nitrogen to a fine powder and total RNA was extracted from $100 \mathrm{mg}$ of powder, following the RNA Plant Purification Reagent protocol according to the manufacturer's instructions (Invitrogen, Villebon sur Yvette, France). The RNA pellet was resuspended in $20 \mu \mathrm{l}$ of RNase-free water. Genomic DNA was removed and RNA purity and concentration was assessed according to Bordiec and associates (2011). Reverse transcription of RNA was performed with $200 \mathrm{ng}$ of total RNA, using M-MLV reverse transcriptase (Invitrogen), according to the manufacturer's protocol.

Real-time reverse-transcription polymerase chain reaction analysis. Polymerase chain reaction (PCR) reactions were carried out in duplicates in 96-well plates $(25 \mu$ per well) in a reaction buffer containing $1 \times$ SYBR Green I mix (Applied Biosystems, Villebon sur Yvette, France) (including Taq polymerase, dNTPs, and SYBR Green dye), $280 \mathrm{nM}$ primers (forward and reverse), and a 1:50 dilution of reverse-transcribed RNA. PCR conditions were $95^{\circ} \mathrm{C}$ for $15 \mathrm{~s}$ (denaturation) and $60^{\circ} \mathrm{C}$ for $1 \mathrm{~min}$ (annealing/extension) for 40 cycles in a GeneAmp 5700 sequence Detection System (Applied Biosystems). Transcript levels were calculated using the standard curve method and normalized against those of the Efl $\alpha$ gene as an internal control (Terrier et al. 2005). Nonbacterized plantlets grown at $26^{\circ} \mathrm{C}$ were used as a reference sample.

The genes and the specific primers used in this study are listed in Table 1 . They correspond to genes encoding a $P A L$, a $S T S$, three PR proteins (Gluc, Chit $4 c$, and Chit lb), a $L O X$, and the transcription factors $C B F 1$ to $C B F 4$.

\section{Analysis of stress-related metabolites.}

Free proline. Proline content was determined using the acid ninhydrin method, as described by Ait Barka and Audran (1997). Proline in leaves was extracted in 3\% (wt/vol) sulfosalicylic acid. The homogenate was filtered through filter paper (Whatman number 1). After addition of $800 \mu$ of ninhydrin reagent, containing $1 \%(\mathrm{wt} / \mathrm{vol})$ ninhydrin in $60 \%$ acetic acid, the mixture was heated to $100^{\circ} \mathrm{C}$ for $20 \mathrm{~min}$ and then cooled in ice. Toluene $(1 \mathrm{ml})$ was added and the sample was vigorously shaken for $15 \mathrm{~s}$. The samples were placed in darkness at room temperature for at least $4 \mathrm{~h}$. The absorbance of the upper phase was read at $520 \mathrm{~nm}$. Proline concentration was determined using a calibration curve and expressed as micromoles of proline per gram dry weight.

$L P$ markers. LP was monitored by analyzing the concentration of thiobarbituric acid-reactive substances according to Ait Barka and associates (2000b). Fresh leaves were ground with Fontainebleau sand and trichloroacetic acid (TCA) $(0.1 \%$ $\mathrm{wt} / \mathrm{vol})$; then, the homogenate was centrifuged at $4{ }^{\circ} \mathrm{C}$ for 10 $\min$ at $12,000 \times g$. One volume of supernatant was mixed with

Table 1. Genes analyzed by real-time reverse-transcription polymerase chain reaction and the primers used

\begin{tabular}{|c|c|c|c|}
\hline Names & Accession number & Forward primers & Reverse primers \\
\hline$E F 1 \alpha$ & BQ799343 & 5'-AACCAAAATATCCGGAGTAAAAGA-3' & 5'-GAACTGGGTGCTTGATAGGC-3' \\
\hline Chit4c & AY 137377 & 5'-TCGAATGCGATGGTGGAAA-3' & 5'-TCCCCTGTCGAAACACCAAG-3' \\
\hline Gluc & AF239617 & 5'-TCAATGGCTGCAATGGTGC-3' & 5'-CGGTCGATGTTGCGAGATTTA-3' \\
\hline Chitlb & Z54234 & 5'-CCCAAGCCTTCCTGCCATA-3' & 5'-TGTGATAACACCAAAACCGGG-3' \\
\hline$P A L$ & X75967 & 5'-TCCTCCCGGAAAACAGCTG-3' & 5'-TCСТCСАAATGCСТCAAATCA-3' \\
\hline$L O X$ & AY159556 & 5'-CCСTTCTTGGCATCTCCCTTA-3' & 5'-TGTTGTGTCCAGGGTCCATTC-3' \\
\hline StSy & X76892 & 5'-AGGAAGCAGCATTGAAGGCTC-3' & 5'-TGCACCAGGCATTTCTACACC-3' \\
\hline$C B F 1$ & AY390372 & 5'-AACCCAACTGCACCATCTTC-3' & 5'-CATCATCCCAGCTGAATCCT-3' \\
\hline$C B F 2$ & AY390376 & 5'-ATGGACTTGGACCGTGAGTC-3' & 5'-ATCGGGAAAATTGAGGGAAG-3' \\
\hline$C B F 3$ & AY390375 & 5'-СССТСАТССТССТСТТССТС-3' & 5'-TCCCCAGCTGAAGATGACTT-3' \\
\hline CBF4 & DQ497624 & 5'-ACCCTCACCCGCTCGTTATG-3' & 5'-CCGCGTCTCCCCGAAACTT-3' \\
\hline
\end{tabular}


four volumes of $20 \%$ TCA containing $0.5 \%$ (wt/vol) 2-thiobarbituric acid. The mixture was heated at $95^{\circ} \mathrm{C}$ for $30 \mathrm{~min}$, quickly cooled in ice, and centrifuged at $10,000 \times g$ for $5 \mathrm{~min}$. The nonspecific absorbance of the supernatant at $600 \mathrm{~nm}$ was subtracted from the maximum absorbance at $532 \mathrm{~nm}$ for MDA measurement and $455 \mathrm{~nm}$ for ALD. For calculations of MDA and ALD concentrations, we used extinction coefficients of $1.56 \times 10^{5} \mathrm{M}^{-1} \mathrm{~cm}^{-1}$ at $532 \mathrm{~nm}$ for MDA and $0.457 \times 10^{5} \mathrm{M}^{-1}$ $\mathrm{cm}^{-1}$ at $455 \mathrm{~nm}$ (the average value obtained for propanal, butanal, hexanal, heptanal, and propanal-dimethylacetal) for ALD. Results are expressed in nanomoles per gram dry weight.

$\mathrm{H}_{2} \mathrm{O}_{2} \cdot \mathrm{H}_{2} \mathrm{O}_{2}$ content was evaluated according to Ait Barka and associates (2000b), with some modifications. Leaf powder (250 mg ) was homogenized in $1 \mathrm{ml}$ of ice-cold acetone and the mixture was centrifuged at $13,500 \times g$ for $10 \mathrm{~min}$. Cold water $(250 \mu \mathrm{l})$ and $100 \mu \mathrm{l}$ of $5 \%$ titanyl sulfate were added to the supernatant, followed by $500 \mu \mathrm{l}$ of $1 \mathrm{~N} \mathrm{NH}_{4} \mathrm{OH}$ solution to precipitate the peroxide-titanium complex. After centrifugation at $6,000 \times g$ for $5 \mathrm{~min}$, the supernatant was discarded and the pellet was washed with cold acetone. The precipitate was then dissolved in $1.5 \mathrm{ml}$ of $2 \mathrm{~N} \mathrm{H}_{2} \mathrm{SO}_{4}$ and the final volume adjusted to $2 \mathrm{ml}$ with cold water. The absorbance of the solution was read at $415 \mathrm{~nm}$, and $\mathrm{H}_{2} \mathrm{O}_{2}$ content was calculated from a standard curve.

\section{Statistical analysis.}

Each experiment was repeated at least three times, with six plantlets per replicate. Reported data are means \pm standard errors (SE) obtained from the three independent experiments, except levels of $C B F 4$ transcripts, for which reported data are means $\pm S E$ of a duplicate from one representative experiment out of three independent experiments. Standard analysis of the variance ( $t$ test) was used to assess the significance of the treatment means at $P<0.05$.

\section{ACKNOWLEDGMENTS}

We thank the Greek State Scholarship Foundation (I.K.Y.) for financial support and F. Rabenoelina for technical assistance.

\section{LITERATURE CITED}

Ait Barka, E., and Audran, J. C. 1997. Response of champenoise grapevine to low temperatures: changes of shoot and bud proline concentrations in response to low temperatures and correlations with freezing tolerance. J Hortic. Sci. 72:577-582.

Ait Barka, E., Belarbi, A., Hachet, C., Nowak, J., and Audran, J. C. 2000a. Enhancement of in vitro growth and resistance to gray mould of Vitis vinifera co-cultured with plant growth-promoting rhizobacteria. FEMS (Fed. Eur. Microbiol. Soc.) Microbiol. Lett. 186:91-95.

Ait Barka, E., Kalantari, S., Makhlouf, J., and Arul, J. 2000b. Effects of UV-C irradiation on lipid peroxidation markers during ripening of tomato (Lycopersicon esculentum L.) fruits. Aust. J. Plant Physiol. 27:147-152.

Ait Barka, E., Nowak, J., and Clement, C. 2006. Enhancement of chilling resistance of inoculated grapevine plantlets with a plant growth-promoting rhizobacterium, Burkholderia phytofirmans strain PsJN. Appl. Environ. Microbiol. 72:7246-7252.

Aziz, A., Poinssot, B., Daire, X., Adrian, M., Bezier, A., Lambert, B., Joubert, J. M., and Pugin, A. 2003. Laminarin elicits defense responses in grapevine and induces protection against Botrytis cinerea and Plasmopara viticola. Mol. Plant-Microbe Interact. 16:1118-1128.

Bell, E., and Mullet, J. E. 1993. Characterization of an Arabidopsis lipoxygenase gene responsive to methyl jasmonate and wounding. Plant Physiol. 103:1133-1137.

Ben-Amor, M., Flores, B., Latche, A., Bouzayen, M., Pech, J. C., and Romojaro, F. 1999. Inhibition of ethylene biosynthesis by antisense ACC oxidase RNA prevents chilling injury in Charentais cantaloupe melons. Plant Cell Environ. 22:1579-1586.

Bertamini, M., Muthuchelian, K., Rubinigg, M., Zorer, R., and Nedunchezhian, N. 2005. Low-night temperature (LNT) induced changes of photosynthesis in grapevine (Vitis vinifera L.) plants. Plant Physiol. Biochem. 43:693-699.
Bordiec, S., Paquis, S., Lacroix, H., Dhondt, S., Ait Barka, E., Kauffmann, S., Jeandet, P., Clément, C., Baillieul, F., and Dorey, S. 2011. Comparative analysis of defence responses induced by the endophytic plant growth-promoting rhizobacterium Burkholderia phytofirmans strain PsJN and the non-host bacterium Pseudomonas syringae pv. pisi in grapevine cell suspensions. J. Exp. Bot. 62:595-603.

Brehm, I., Preisig-Muller, R., and Kindl, H. 1999. Grapevine protoplasts as a transient expression system for comparison of stilbene synthase genes containing cGMP-responsive promoter elements. Z. Naturforsch. C. 54:220-229.

Chen, W. P., and Li, P. H. 2002. Membrane stabilization by abscisic acid under cold aids proline in alleviating chilling injury in maize (Zea mays L.) cultured cells. Plant Cell Environ. 25:955-962.

Chinnusamy, V., Zhu, J., and Zhu, J.-K. 2006. Gene regulation during cold acclimation in plants. Physiol. Plant. 126:52-61.

Chong, J., Poutaraud, A., and Hugueney, P. 2009. Metabolism and roles of stilbenes in plants. Plant Sci. 177:143-155.

Compant, S., Duffy, B., Nowak, J., Clement, C., and Ait Barka, E. 2005a. Use of plant growth-promoting bacteria for biocontrol of plant diseases: principles, mechanisms of action, and future prospects. Appl. Environ. Microbiol. 71:4951-4959.

Compant, S., Reiter, B., Sessitsch, A., Nowak, J., Clement, C., and Ait Barka, E. 2005b. Endophytic colonization of Vitis vinifera L. by plant growth-promoting bacterium Burkholderia sp. strain PsJN. Appl. Environ. Microbiol. 71:1685-1693.

Compant, S., Kaplan, H., Sessitsch, A., Nowak, J., Ait Barka, E., and Clement, C. 2008a. Endophytic colonization of Vitis vinifera L. by Burkholderia phytofirmans strain PsJN: from the rhizosphere to inflorescence tissues. FEMS (Fed. Eur. Microbiol. Soc.) Microbiol. Ecol. 63:84-93.

Compant, S., Nowak, J., Coenye, T., Clement, C., and Ait Barka, E. 2008b. Diversity and occurrence of Burkholderia spp. in the natural environment. FEMS (Fed. Eur. Microbiol. Soc.) Microbiol. Rev. 32:607-626.

Concellon, A., Anon, M. C., and Chaves, A. R. 2005. Effect of chilling on ethylene production in eggplant fruit. Food Chem. 92:63-69.

Conrath, U. 2009. Priming of induced plant defense responses. In: Advances in Botanical Research. L. C. V. Loon, ed. Academic Press, Burlington, VT, U.S.A.

Conrath, U., Beckers, G. J. M., Flors, V., Garcia-Agustin, P., Jakab, G., Mauch, F., Newman, M.-A., Pieterse, C. M. J., Poinssot, B., Pozo, M. J., Pugin, A., Schaffrath, U., Ton, J., Wendehenne, D., Zimmerli, L., and Mauch-Mani, B. 2006. Priming: getting ready for battle. Mol. PlantMicrobe Interact. 19:1062-1071.

Dimkpa, C., Weinand, T., and Asch, F. 2009. Plant-rhizobacteria interactions alleviate abiotic stress conditions. Plant Cell Environ. 32:1682-1694.

Ding, S., Huang, C. L., Sheng, H. M., Song, C. L., Li, Y. B., and An, L. Z. 2011. Effect of inoculation with the endophyte Clavibacter sp. strain Enf12 on chilling tolerance in Chorispora bungeana. Physiol. Plant. 141:141-151.

Frost, C. J., Mescher, M. C., Carlson, J. E., and De Moraes, C. M. 2008. Plant defense priming against herbivores: getting ready for a different battle. Plant Physiol. 146:818-824.

Gaudet, D. A., Laroche, A., Frick, M., Huel, R., and Puchalski, B. 2003. Plant development affects the cold-induced expression of plant defencerelated transcripts in winter wheat. Physiol. Mol. Plant Pathol. 62:175184.

Gilmour, S. J., Sebolt, A. M., Salazar, M. P., Everard, J. D., and Thomashow, M. F. 2000. Overexpression of the Arabidopsis CBF3 transcriptional activator mimics multiple biochemical changes associated with cold acclimation. Plant Physiol. 124:1854-1865.

Griffith, M., and Yaish, M. W. 2004. Antifreeze proteins in overwintering plants: a tale of two activities. Trends Plant Sci. 9:399-405.

Hamiduzzaman, M. M., Jakab, G., Barnavon, L., Neuhaus, J. M., and Mauch-Mani, B. 2005. $\beta$-Aminobutyric acid-induced resistance against downy mildew in grapevine acts through the potentiation of callose formation and jasmonic acid signaling. Mol. Plant-Microbe Interact. 18:819-829.

He, C. Y., and Wolyn, D. J. 2005. Potential role for salicylic acid in induced resistance of asparagus roots to Fusarium oxysporum f. sp. asparagi. Plant Pathol. 54:227-232.

Hekneby, M., Carmen Antolín, M., and Sánchez-Díaz, M. 2006. Frost resistance and biochemical changes during cold acclimation in different annual legumes. Environ. Exp. Bot. 55:305-314.

Huang, T., and Duman, J. G. 2002. Cloning and characterization of a thermal hysteresis (antifreeze) protein with DNA-binding activity from winter bittersweet nightshade, Solanum dulcamara. Plant Mol. Biol. 48:339-350.

Imahori, Y., Takemura, M., and Bai, J. 2008. Chilling-induced oxidative stress and antioxidant responses in mume (Prunus mume) fruit during low temperature storage. Postharvest Biotechnol. 49:54-60. 
Kishor, P. B. K., Sangam, S., Amrutha, R. N., Laxmi, P. S., Naidu, K. R., Rao, K., Rao, S., Reddy, K. J., Theriappan, P., and Sreenivasulu, N. 2005. Regulation of proline biosynthesis, degradation, uptake and transport in higher plants: its implications in plant growth and abiotic stress tolerance. Curr. Sci. 88:424-438.

Lee, S. H., Ahn, S. J., Im, Y. J., Cho, K., Chung, G. C., Cho, B. H., and Han, O. 2005. Differential impact of low temperature on fatty acid unsaturation and lipoxygenase activity in figleaf gourd and cucumber roots. Biochem. Biophys. Res. Commun. 330:1194-1198.

Liu, Q., Kasuga, M., Sakuma, Y., Abe, H., Miura, S., Yamaguchi-Shinozaki, K., and Shinozaki, K. 1998. Two transcription factors, DREB1 and DREB2, with an EREBP/AP2 DNA binding domain separate two cellular signal transduction pathways in drought- and low-temperatureresponsive gene expression, respectively, in Arabidopsis. Plant Cell 10:1391-1406.

Nakashima, K., and Yamaguchi-Shinozaki, K. 2006. Regulons involved in osmotic stress-responsive and cold stress-responsive gene expression in plants. Physiol. Plant. 126:62-71.

Nowak, J., and Shulaev, V. 2003. Priming for transplant stress resistance in In vitro propagation. In Vitro Cell Dev. Plant 39:107-124.

Pavlo, A., Leonid, O., Iryna, Z., Natalia, K., and Maria, P. A. 2011. Endophytic bacteria enhancing growth and disease resistance of potato ( $\mathrm{So}$ lanum tuberosum L.). Biol. Control 56:43-49.

Patton, A. J., Cunningham, S. M., Volenec, J. J., and Reicher, Z. J. 2007. Differences in freeze tolerance of zoysiagrasses: II. Carbohydrate and proline accumulation. Crop Sci. 47:2170-2181.

Pinhero, R. G., Rao, M. V., Paliyath, G., Murr, D. P., and Fletcher, R. A. 1997. Changes in activities of antioxidant enzymes and their relationship to genetic and paclobutrazol-induced chilling tolerance of maize seedlings. Plant Physiol. 114:695-704.

Pozo, M. J., Van Der Ent, S., Van Loon, L. C., and Pieterse, C. M. J. 2008 Transcription factor MYC2 is involved in priming for enhanced defense during rhizobacteria-induced systemic resistance in Arabidopsis thaliana. New Phytol. 180:511-523.

Prasad, T. K., Anderson, M. D., Martin, B. A., and Stewart, C. R. 1994. Evidence for chilling-induced oxidative stress in maize seedlings and a regulatory role for hydrogen peroxide. Plant Cell 6:65-74.

Preisig-Muller, R., Schwekendiek, A., Brehm, I., Reif, H. J., and Kindl, H. 1999. Characterization of a pine multigene family containing elicitorresponsive stilbene synthase genes. Plant Mol. Biol. 39:221-229.

Ruelland, E., Vaultier, M.-N., Zachowski, A., Hurry, V., and Kader, J.-C. and Michel, D. 2009. Cold signalling and cold acclimation in plants. Adv. Bot. Res. 49:35-150.

Sanchez-Ballesta, M. T., Romero, I., Jiménez, J. B., Orea, J. M., GonzálezUreña, A., Escribano, M. I., and Merodio, C. 2007. Involvement of the phenylpropanoid pathway in the response of table grapes to low temperature and high $\mathrm{CO}_{2}$ levels. Postharvest Biotechnol. 46:29-35.

Sessitsch, A., Coenye, T., Sturz, A. V., Vandamme, P., Ait Barka, E., Salles, J. F., Van Elsas, J. D., Faure, D., Reiter, B., Glick, B. R., Wang-Pruski, G., and Nowak, J. 2005. Burkholderia phytofirmans sp. nov., a novel plant-associated bacterium with plant-beneficial properties. Int. J. Syst. Evol. Microbiol. 55:1187-1192.

Sharma, V. K., and Nowak, J. 1998. Enhancement of Verticillium wilt resistance in tomato transplants by in vitro co-culture of seedlings with a plant growth promoting rhizobacterium (Pseudomonas sp. strain PsJN). Can. J. Microbiol. 44:528-536.

Slaughter, A. R, Hamiduzzaman, M. M., Gindro, K., Neuhaus, J.-M., and Mauch-Mani, B. 2008. Beta-aminobutyric acid-induced resistance in grapevine against downy mildew: involvement of pterostilbene. Eur. J. Plant Pathol. 122:185-195.

Takuhara, Y, Kobayashi, M., and Suzuki, S. 2011. Low-temperatureinduced transcription factors in grapevine enhance cold tolerance in transgenic Arabidopsis plants. J. Plant Physiol. 168:967-75.

Tattersall, E. A., Grimplet, J., DeLuc, L., Wheatley, M. D., Vincent, D., Osborne, A. Ergul, E. Lomen, R. R. Blank, K. A. Schlauch, J. C Cushman, C., and Cramer, G. R. 2007. Transcript abundance profiles reveal larger and more complex responses of grapevine to chilling compared to osmotic and salinity stress. Funct. Integr. Genomic 7:317-333.
Terrier, N., Glissant, D., Grimplet, J., Barrieu, F., Abbal, P., Couture, C., Ageorges, A., Atanassova, R., Leon, C., Renaudin, J. P., Dedaldechamp, F., Romieu, C., Delrot, S., and Hamdi, S. 2005. Isogene specific oligo arrays reveal multifaceted changes in gene expression during grape berry (Vitis vinifera L.) development. Planta 222:832-847.

Thomashow, M. F. 1999. Plant cold acclimation: freezing tolerance genes and regulatory mechanisms. Annu. Rev. Physiol. 50:571-599.

Thulke, O., and Conrath, U. 1998. Salicylic acid has a dual role in the activation of defence-related genes in parsley. Plant J. 14:35-42.

Tjamos, S. E., Flemetakis, E., Paplomatas, E. J., and Katinakis, P. 2005. Induction of resistance to Verticillium dahliae in Arabidopsis thaliana by the biocontrol agent K-165 and pathogenesis-related proteins gene expression. Mol. Plant-Microbe Interact. 18:555-561.

Ton, J., Jakab, G., Toquin, V., Flors, V., Iavicoli, A., Maeder, M. N., Metraux, J.-P., and Mauch-Mani, B. 2005. Dissecting the beta-aminobutyric acid-induced priming phenomenon in Arabidopsis. Plant Cell 17:987-999.

Trouvelot, S., Varnier, A. L., Allègre, M., Mercier, L., Baillieul, F., Arnould, C., Gianinazzi-Pearson, V., Klarzynski, O., Joubert, J. M., Pugin, A., and Daire, X. 2007. A $\beta-1,3$ glucan sulfate induces resistance in grapevine against Plasmopara viticola through priming of defense responses, including HR-like cell death. Mol. Plant-Microbe Interact. 21:232-243.

Uemura, M., and Steponkus, P. L. 1999. Cold acclimation in plants: relationship between the lipid composition and the cryostability of the plasma membrane. J. Plant Res. 112:245-254.

Van Loon, L. C., and Van Strien, E. A. 1999. The families of pathogenesisrelated proteins, their activities, and comparative analysis of PR-1 type proteins. Physiol. Mol. Plant Pathol. 55:85-97.

Van Wees, S. C. M., Van der Ent, S., and Pieterse, C. M. J. 2008. Plant immune responses triggered by beneficial microbes. Curr. Opin. Plant Biol. 11:443-448.

Varnier, A. L., Sanchez, L., Vatsa, P., Boudesocque, L., Garcia-Brugger, A., Rabenoelina, F., Sorokin, A., Renault, J. H., Kauffmann, S., Pugin, A., Clement, C., Baillieul, F., and Dorey, S. 2009. Bacterial rhamnolipids are novel MAMPs conferring resistance to Botrytis cinerea in grapevine. Plant, Cell Environ. 32:178-193.

Verhagen, B. W., Trotel-Aziz, P., Couderchet, M., Hofte, M., and Aziz, A. 2010. Pseudomonas spp.-induced systemic resistance to Botrytis cinerea is associated with induction and priming of defence responses in grapevine. J. Exp. Bot. 61:249-260.

Versari, A., Parpinello, G. P., Tornielli, G. B., Ferrarini, R., and Giulivo, C. 2001. Stilbene compounds and stilbene synthase expression during ripening, wilting, and UV treatment in grape cv. Corvina. J. Agric. Food Chem. 49:5531-5536.

Wang, W.-J., Chen, Y.-Z., Liu, M.-Q., and Lu, C.-F. 2008. Effects of coldhardening on compatible solutes and antioxidant enzyme activities related to freezing tolerance in Ammopiptanthus mongolicus seedlings. For. Stud. China 10:101-106.

Wong, C. E., Li, Y., Labbe, A., Guevara, D., Nuin, P., Whitty, B., Diaz, C., Golding, G. B., Gray, G. R., Weretilnyk, E. A., Griffith, M., and Moffatt, B. A. 2006. Transcriptional profiling implicates novel interactions between abiotic stress and hormonal responses in Thellungiella, a close relative of Arabidopsis. Plant Physiol. 140:1437-1450.

Xiao, H., Siddiqua, M., Braybrook, S., and Nassuth, A. 2006. Three grape CBF/DREB1 genes respond to low temperature, drought and abscisic acid. Plant Cell Environ. 29:1410-1421.

Xiao, H., Tattersall, E. A., Siddiqua, M. K., Cramer, G. R., and Nassuth, A. 2008. CBF4 is a unique member of the CBF transcription factor family of Vitis vinifera and Vitis riparia. Plant Cell Environ. 31:1-10.

Xin, Z., and Browse, J. 2000. Cold comfort farm: the acclimation of plants to freezing temperatures. Plant Cell Environ. 23:893-902.

Yeh, S., Moffatt, B. A., Griffith, M., Xiong, F., Yang, D. S., Wiseman, S. B., Sarhan, F., Danyluk, J., Xue, Y. Q., Hew, C. L., Doherty-Kirby, A., and Lajoie, G. 2000. Chitinase genes responsive to cold encode antifreeze proteins in winter cereals. Plant Physiol. 124:1251-1264.

Zhou, X., Wang, G., Sutoh, K., Zhu, J. K., and Zhang, W. 2008. Identification of cold-inducible microRNAs in plants by transcriptome analysis. Biochim. Biophys. Acta 1779:780-788. 